University of Nebraska - Lincoln

DigitalCommons@University of Nebraska - Lincoln

USDA Wildlife Services - Staff Publications

U.S. Department of Agriculture: Animal and Plant Health Inspection Service

6-1-2021

\title{
Comparing Management Programs to Reduce Red-tailed Hawk Collisions with Aircraft
}

Brian Washburn

USDA NWRC, brian.e.washburn@usda.gov

Craig K. Pullins

USDA Animal and Plant Health Inspection Service (APHIS)

Travis L. Guerrant

United States Department of Agriculture

Gregory J. Martinelli

USDA Animal and Plant Health Inspection Service (APHIS)

Scott F. Beckerman

USDA Animal and Plant Health Inspection Service (APHIS)

Follow this and additional works at: https://digitalcommons.unl.edu/icwdm_usdanwrc

Part of the Natural Resources and Conservation Commons, Natural Resources Management and

Policy Commons, Other Environmental Sciences Commons, Other Veterinary Medicine Commons,

Population Biology Commons, Terrestrial and Aquatic Ecology Commons, Veterinary Infectious Diseases

Commons, Veterinary Microbiology and Immunobiology Commons, Veterinary Preventive Medicine,

Epidemiology, and Public Health Commons, and the Zoology Commons

Washburn, Brian; Pullins, Craig K.; Guerrant, Travis L.; Martinelli, Gregory J.; and Beckerman, Scott F., "Comparing Management Programs to Reduce Red-tailed Hawk Collisions with Aircraft" (2021). USDA Wildlife Services - Staff Publications. 2494.

https://digitalcommons.unl.edu/icwdm_usdanwrc/2494

This Article is brought to you for free and open access by the U.S. Department of Agriculture: Animal and Plant Health Inspection Service at DigitalCommons@University of Nebraska - Lincoln. It has been accepted for inclusion in USDA Wildlife Services - Staff Publications by an authorized administrator of DigitalCommons@University of Nebraska - Lincoln. 


\title{
Comparing Management Programs to Reduce Red-tailed Hawk Collisions with Aircraft
}

\author{
BRIAN E. WASHBURN, ${ }^{1}$ USDA, Wildlife Services, National Wildlife Research Center, 6100 Columbus Avenue, Sandusky, Obio 44870, USA \\ CRAIG K. PULLINS, USDA, APHIS, Wildlife Services, O'Hare International Airport, AMC Building, Room 241, Chicago, Illinois 60666, USA \\ TRAVIS L. GUERRANT, USDA, APHIS, Wildlife Services, 1714 Commerce Court, Suite C, Columbia, Missouri 65202, USA \\ GREGORY J. MARTINELLI, USDA, APHIS, Wildlife Services, O'Hare International Airport, AMC Building, Room 241, Chicago, \\ Illinois 60666, USA \\ SCOTT F. BECKERMAN, USDA, APHIS, Wildlife Services, 3430 Constitution Drive, Suite 121, Springfield, Illinois 62711, USA
}

\begin{abstract}
Wildlife-aircraft collisions (wildlife strikes) pose a serious safety risk to aircraft. Raptors (i.e., hawks and owls) are one of the most frequently struck guilds of birds within North America. Although raptors (most notably red-tailed hawks [Buteo jamaicensis]) are commonly managed at most airports and military bases, there is no scientific information available regarding comparisons of the efficacy of raptor management programs for reducing raptor-aircraft collisions. Therefore, we conducted a study to examine the efficacy of 2 raptor hazard management programs implemented at Chicago's O'Hare International Airport (ORD). The first raptor management program (Phase I) occurred during January 2010-June 2013 and was characterized by intensive and sustained live-trapping and translocation efforts. The second raptor management program (Phase II) occurred during July 2013-December 2016 and involved live-trapping and translocation of specific age classes and increased lethal removal of problematic individual hawks. Compared with Phase I, there were 47\% fewer red-tailed hawk strikes (52 in Phase I and 28 in Phase II) and $67 \%$ fewer damaging red-tailed hawk strikes (6 in Phase I and 2 in Phase II) during Phase II of the management programs. Our findings demonstrate that airport wildlife management decisions based on scientific data and biological information can aid in reducing wildlife strikes, financial losses, and ultimately airport liability while increasing human safety. The decision matrix regarding the components of an airport raptor hazard management program involves a variety of biological, geographic, logistical, economic, and socio-political variables. Our study provides a scientific foundation for informing such management decisions. Published 2021. This article is a U.S. Government work and is in the public domain in the USA.
\end{abstract}

KEY WORDS airports, bird strikes, economics, Buteo jamaicensis, management, raptors, red-tailed hawks.

Wildlife-aircraft collisions (wildlife strikes) pose a serious safety risk to aircraft and the flying public. The total cost of wildlife strikes to commercial aviation world-wide has been estimated to be more than US\$1.5 billion per year (Allan et al. 2016). Wildlife strike costs to civil aviation (i.e., direct repair of aircraft costs) in the United States have conservatively been estimated to exceed US\$965 million annually (Dolbeer 2018), but the actual costs (incorporating aircraft down time, the cost of putting passengers in hotels, and other indirect costs) are likely much higher (Anderson et al. 2015). Raptors (e.g., hawks and owls) are one of the most frequently struck bird guilds within North America (Dolbeer 2018), and pose a serious safety risk to civil (DeVault et al. 2011, Washburn et al. 2015, Linnell and

Received: 6 November 2019; Accepted: 25 October 2020

Published: 19 May 2021

${ }^{1}$ E-mail: brian.e.washburn@usda.gov
Washburn 2018) and military aircraft (Zakrajsek and Bissonette 2005, Pfeiffer et al. 2018).

Implementation of management actions to reduce the presence and abundance of hazardous wildlife (e.g., raptor) numbers on and around airports is critical for safe airport operations (Cleary and Dolbeer 2005, DeVault et al. 2013). Integrated wildlife damage management programs combine a variety of non-lethal and lethal management tools to reduce presence of raptors on airports, which ultimately reduces the probability of raptor-aircraft collisions (DeVault et al. 2013, Guerrant et al. 2013). Commonly used methods to manage raptors (and other hazardous wildlife) include non-lethal hazing with pyrotechnics (Marsh et al. 1991), mitigation translocation (i.e., live-capture and translocation of problematic individuals; Schafer and Washburn 2016, Biteman et al. 2019), prey management (Washburn et al. 2011, Witmer 2011), and lethal removal of problematic individuals (Dolbeer et al. 1993, Baxter and Allan 2008). Given high public interest, logistical and financial constraints, federal and 
state regulations, and other factors, managing raptors at airports presents some unique challenges (Washburn 2018).

Red-tailed hawks (Buteo jamaicensis) are one of the most abundant and wide-spread raptors in North America. During 1966-2015, red-tailed hawk populations increased annually by $3.5 \%$ in Illinois and $1.7 \%$ in the USA (Sauer et al. 2017). Red-tailed hawks are commonly involved in collisions with civilian and military aircraft and pose an important risk to aviation safety (Zakrajsek and Bissonette 2005, Blackwell and Wright 2006, Dolbeer 2018). DeVault et al. (2018) found that among the 79 bird species they evaluated, red-tailed hawks posed the highest strike risk to civil aviation in the USA (nationally), as well as the highest risk (locally) at 3 of 4 major U.S. airports. During 2007-2012, red-tailed hawks accounted for the majority of damaging wildlife strikes to aircraft at Chicago's O'Hare International Airport, and consequently their management is a major focus of the integrated wildlife damage management program at the airport (Guerrant et al. 2013).

To our knowledge, there is no published information available regarding the efficacy and economics of raptor hazard management programs for reducing the abundance of raptors on airfields and thus reducing the frequency of raptor-aircraft collisions at airports. Consequently, scientific evaluations are needed as they are essential for the development of effective raptor hazard management programs within airport environments. We conducted our study to increase understanding of the efficacy of wildlife mitigation programs in reducing the frequency of aircraft strikes involving red-tailed hawks. The objectives of our study were to: 1) describe and summarize the components of 2 raptor management programs implemented at a major civilian airport, 2) evaluate red-tailed hawk airfield abundance and hawk strikes with aircraft that occurred during the implementation of these programs, and 3) examine the economic costs of raptor management programs.

\section{STUDY AREA}

We conducted our study at Chicago's O'Hare International Airport (ORD) in Chicago, Illinois ( $\left.41^{\circ} 58^{\prime} 43^{\prime \prime} \mathrm{N}, 87^{\circ} 54^{\prime} 17^{\prime \prime} \mathrm{W}\right)$. This airport was operated by the Chicago Department of Aviation and encompasses approximately 2,950 ha (Chicago Department of Aviation 2014). In 2017, there were over 79 million passengers and 867,049 aircraft operations at the airport, making ORD one of the largest and busiest civilian airports in the world (McMillen 2004, Airports Council International 2017).

The airfield at ORD was comprised of a variety of land covers, including pavement/buildings ( $1,281 \mathrm{ha})$, grasslands (1,375 ha), areas under construction (232 ha), and forest/ shrublands $(24.7 \mathrm{ha})$. In addition, numerous water control structures (e.g., retention ponds) and drainage areas were distributed throughout the airport property (Chicago Department of Aviation 2014). Mean annual precipitation at the airport was $930 \mathrm{~mm}$ per year with $56 \%$ typically falling as snow during October-April (Calsyn et al. 2012).
Average daily temperatures were $22.2^{\circ} \mathrm{C}$ during summer and $-4.1^{\circ} \mathrm{C}$ during winter.

\section{METHODS}

We assigned all live-captured red-tailed hawks, as well as those involved in collisions with aircraft (i.e., hawk strikes), to age classes based on plumage and eye coloration (Pyle 2008, Preston and Beane 2009). Hatch-year (HY) birds were less than 12 months old at the time of capture or recovery. Second-year (SY) birds were between 12 and 24 months of age, whereas after-second year birds (ASY) were more than 24 months of age at the time of capture or recovery. As with all raptor species, red-tailed hawks are protected by the Migratory Bird Treaty Act (16 USC $\S \S 703-712)$. All raptor management activities at ORD were conducted under federal and state permits issued by the U.S. Fish and Wildlife Service (\#MB020299) and the Illinois Department of Natural Resources (Class E, Nuisance Wildlife Control Permit), respectively.

\section{Phase I Management Program}

During 1 January 2010-30 June 2013, the first of the raptor hazard management programs was conducted at ORD. The hazard management program included both non-lethal and lethal methods, with a particular emphasis on mitigation by translocations of red-tailed hawks. A variety of standard live-capture methods were employed to capture red-tailed hawks that were presenting a hazard to aircraft at ORD, including Swedish goshawk traps, pole traps, and bal-chatri traps (Bub 1991, Bloom et al. 2007). Red-tailed hawks of all age classes (HY, SY, and ASY) were translocated from ORD during all months of the year and up to a total of 3 times. Translocated birds were released at 4 different locations, located $81 \mathrm{~km}, 121 \mathrm{~km}, 161 \mathrm{~km}$, and $204 \mathrm{~km}$, respectively, west of the airport. Specific details regarding the mitigation translocations conducted during Phase I can be found in Pullins et al. (2018).

Pullins et al. (2018) found that the age class of the birds, the season of the year (i.e., breeding vs. non-breeding), and the number of times an individual hawk was translocated influenced the return rates of red-tailed hawks following a mitigation translocation. Based on their findings, they developed a decision matrix for the management of red-tailed hawks (Pullins et al. 2018).

We queried the USDA APHIS Wildlife Services (WS) Management Information System (MIS) database and extracted all records pertaining to the management of redtailed hawks at ORD during Phase I. Available information included the action taken, methods and tools used, and the resulting fate of the hawks involved (e.g., mitigation translocation, lethal removal). Lethal removal was used when it was necessary to mitigate emergency situations related to human health and safety following the repeated application of non-lethal methods.

\section{Phase II Management Program}

The Phase II raptor management program was conducted during 1 July 2013-31 December 2016 and was essentially 
modeled after the proposed management framework found in Pullins et al. (2018). The Phase II management program also included the same non-lethal and lethal components used in the first program, but the guidelines for the implementation of the various methods were different. During Phase II, there was a greater emphasis placed on the use of non-lethal hazing tools (e.g., pyrotechnics, vehicle hazing) and lethal removal of problematic individuals, as well as specific guidelines regarding mitigation translocations (i.e., HY hawks were only translocated during the non-breeding season). As for Phase I, we queried the Wildlife Services' MIS database and extracted all records pertaining to the management of red-tailed hawks at ORD during Phase II.

Mitigation translocations included HY birds and occurred only during the non-breeding season (July through December). All other red-tailed hawks found on the airfield were managed using hazing methods or were lethally removed. A total of $316 \mathrm{HY}$ red-tailed hawks live-captured at ORD during Phase II were banded with a standard U.S. Geological Survey leg band and marked with a pair of patagial tags (one on each wing; Varland et al. 2007, Pullins et al. 2018). Patagial wing tags were identical to those used during Phase I of the study and details can be found in Pullins et al. (2018). Hawks were held in captivity for less than $48 \mathrm{hr}$ under climate-controlled conditions, in individual cages, and with minimal human disturbance. Individuals were released at Castle Rock State Park (41 $58^{\prime}$ $40^{\prime \prime} \mathrm{N}, 89^{\circ} 21^{\prime} 25^{\prime \prime} \mathrm{W}$ ), which is located near Oregon, IL and is approximately $121 \mathrm{~km}$ (75 miles) west of ORD. Land covers at the release site were comprised of a mixture of forest/woodlands, grasslands, and agricultural areas.

\section{Monitoring for Returns and Airfield Abundance of Red- tailed Hawks}

Following Pullins et al. (2018), we define a raptor return as any situation in which an individual red-tailed hawk was resighted (i.e., visually observed) or recovered (e.g., recaptured, struck by aircraft, found dead) on the airport following a mitigation translocation of that individual hawk. Live-trapping activities for raptors, standard avian pointcount surveys for hazardous wildlife (Cleary and Dolbeer 2005), and continual monitoring efforts during daily wildlife detection and hazard management activities were conducted on the airfield at ORD from January 2010 (the start of this study) to December 2016 (after the marking phases of the project ended). During 2010-2016, WS personnel conducted a series of standard avian surveys each month (averaging 2 surveys per month) at random start times and locations (Bibby et al. 2000). During each survey, a 3-min, fixed-area point count (200-m radius) was conducted at 15 pre-determined locations on the ORD airfield. We extracted all observations of red-tailed hawks during these surveys for our analyses.

\section{Red-tailed Hawk Strikes with Aircraft}

We queried the Federal Aviation Administration's National Wildlife Strike Database (Dolbeer 2018) and extracted all records that involved red-tailed hawks at ORD from
1 January 2010 to 31 December 2016. In addition, we obtained additional information about many of these strike events because all struck birds and strike events occurring at ORD are reviewed by USDA-WS personnel per airport policy. We found a total of 80 red-tailed hawk strike records, which contained varying levels of information among them (for example, not all records contained age class data). We standardized the number of reported red-tailed hawk strikes per 100,000 aircraft operations (an aircraft operation is defined as an arrival or departure of an aircraft) based on data from the air traffic activity system (Federal Aviation Administration 2018).

\section{Economic Costs}

We estimated the economic costs of the mitigation translocations conducted during each of the raptor management programs. Following Pullins et al. (2018), we only included personnel and mileage costs directly associated with the translocation of red-tailed hawks. Personnel costs to translocate hawks were based on a standard salary and benefits rate of US\$34.39 per hour (Pullins et al. 2018). We used an estimated mileage cost of US $\$ 0.73$ per mile (obtained from the American Automotive Association, Heathrow, Florida, USA; http://www.aaa.com). In our evaluation, we did not take into account the costs to live-capture and handle the hawks, which included costs such as personnel, vehicle use, and field equipment (Pullins et al. 2018).

We defined a hawk strike as a damaging strike if there was any reported amount of damage to the aircraft. Based on information provided in Dolbeer (2018), the average estimated cost of a red-tailed hawk damaging strike to a civil aircraft was US\$85,564.

\section{Statistical Analyses}

We summarized the management actions taken, types of live traps used, return rates of translocated hawks, and redtailed hawk strikes among hawk age classes using descriptive statistics. We used Student $t$-tests to compare the airfield abundance of red-tailed hawks and the average number of red-tailed hawk strikes per year between Phase I and Phase II (Zar 1996). We used comparison of proportion tests (Zar 1996) to compare the proportion of non-lethal hazing, mitigation translocations, and lethal actions between the two management programs and the proportion of returning HY hawks during Phase I and Phase II. We considered differences significant at $P \leq 0.05$ and conducted all statistical analyses using SAS 9.4 (SAS Institute, Cary, NC, USA). Results are presented as mean $( \pm 1 \mathrm{SE})$.

\section{RESULTS}

\section{Management Program Characteristics}

During Phase I, a total of 980 management actions were conducted involving red-tailed hawks that posed a risk to safe aircraft operations at ORD (an average of 280 actions/yr). A total of 1,070 management actions were conducted involving red-tailed hawks at ORD during Phase II (an average of 306 actions/yr). Across both management programs, vehicles, firearms, and pyrotechnics were used in $6.8 \%, 20.7 \%$, and 
Table 1. Management actions taken to reduce the risk of red-tailed hawk strikes with aircraft during 2 raptor hazard management programs conducted at Chicago's O'Hare International Airport, Chicago, Illinois, USA, 2010-2016.

\begin{tabular}{lcc}
\hline Method & Phase I & Phase II \\
\hline Non-lethal hazing (all) & 23 & 228 \\
Vehicle & 5 & 12 \\
Firearms & 13 & 39 \\
Pyrotechnics & 5 & 177 \\
Translocations & $788^{\mathrm{a}}$ & $415^{\mathrm{b}}$ \\
Lethal removal (all) & 167 & 427 \\
Firearms & 144 & 208 \\
Trap \& euthanize & 23 & 219 \\
\hline
\end{tabular}

${ }^{a}$ Of these mitigation translocations, 610 involved red-tailed hawks marked with unique patagial wing tags, as reported in Pullins et al. (2018).

${ }^{\mathrm{b}}$ Of these mitigation translocations, 316 involved HY red-tailed hawks marked with unique patagial wing tags.

$72.5 \%$ of the non-lethal hazing actions, respectively (Table 1). Of the lethal removal events, $59.1 \%$ involved the use of firearms and $40.9 \%$ involved the use of trapping and humane euthanasia (Table 1).

During the Phase II management program, 9.9 times more $(z=13.02, P<0.001)$ non-lethal hazing events occurred, approximately half as many $(z=19.07, P<0.001)$ hawks were live-trapped and translocated, and 2.5 times more $(z=11.34, P<0.001)$ lethal removals were conducted relative to Phase I (Table 1). For every lethal action taken during Phase I, 4.8 non-lethal activities were conducted, whereas for every lethal action taken during Phase II, 1.5 non-lethal activities were conducted.

Several types of raptor traps were used to capture redtailed hawks during the management programs. Trapping effort information was not available for analysis. The frequency of red-tailed hawk captures by trap type varied between the Phase I and Phase II management programs (Fig. 1). Bal-chatri traps accounted for more hawk captures during Phase I (16.6\% of all hawk captures) than during Phase II (2.8\% of all hawk captures). Similarly, pole traps accounted for a higher proportion of red-tailed hawk captures during Phase I (26.1\% of captures) than during Phase II (6.5\% of captures). Swedish goshawk traps were the most commonly used trap during both Phase I and Phase II, but this method resulted in more hawks being captured during Phase II (90.7\% of captures) relative to Phase I (57.2\% of captures).

\section{Return Rates of Translocated Hawks}

Of the $90 \mathrm{HY}$ red-tailed hawks that were translocated from ORD during the fall or winter during Phase I, 14 (15.6\%) returned to the airfield (Pullins et al. 2018). A similar $(z=1.15, P=0.25)$ proportion (33 of 316 , i.e., $10.4 \%)$ of patagial tagged and translocated HY hawks returned to the ORD airfield, during Phase II of the study.

\section{Airfield Abundance of Red-tailed Hawks}

We observed more $\left(t_{4}=3.51, P=0.01\right)$ red-tailed hawks per survey on the ORD airfield during Phase I $(3.6 \pm 0.5)$ than during Phase II $(1.4 \pm 0.6)$. Overall, red-tailed hawk

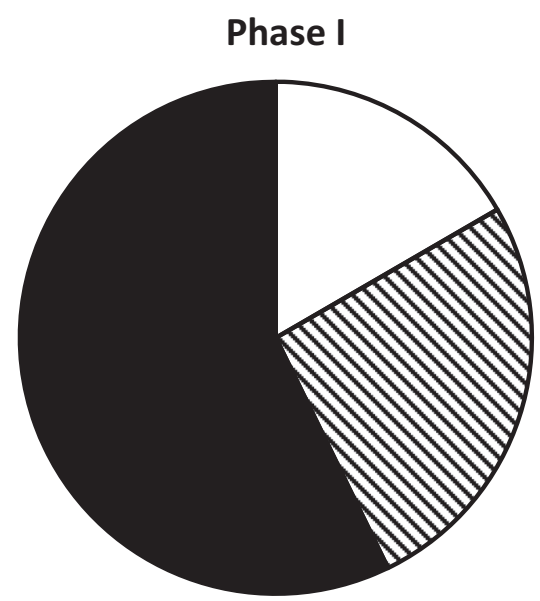

\section{Bal-chatri $\boldsymbol{\Delta}$ Pole trap $\square$ Swedish Goshawk Trap}

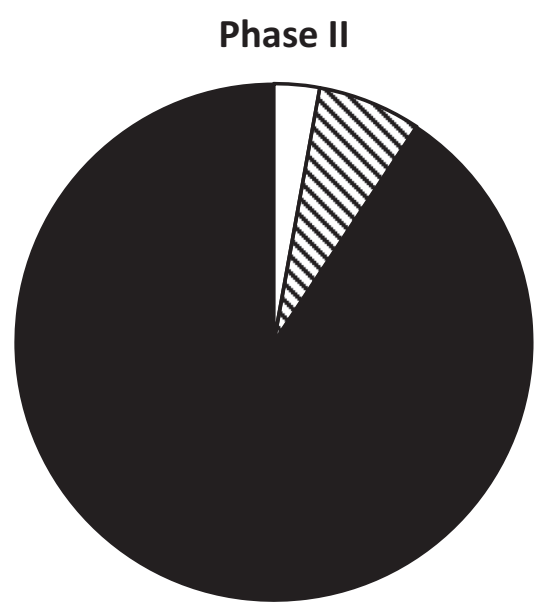

Bal-chatri $\Delta$ Pole trap $\square$ Swedish Goshawk Trap

Figure 1. Distribution of raptor trap types used to live-capture red-tailed hawks during 2 raptor hazard management programs conducted at Chicago's O'Hare International Airport, Chicago, Illinois, USA, 2010-2016.

abundance on the airfield was highest during the fall migratory period (August through October) and lowest during the early breeding season (April through June).

Table 2. Reported red-tailed hawk strikes with aircraft (reported strikes per 100,000 aircraft movements), by hawk age class, during 2 raptor hazard management programs conducted at Chicago's O'Hare International Airport, Chicago, Illinois, USA, 2010-2016.

\begin{tabular}{lrrr}
\hline Age class & Phase I & Phase II & \multicolumn{1}{c}{ Total } \\
\hline HY $^{\mathrm{a}}$ & $6(0.20)$ & $1(0.03)$ & $7(0.11)$ \\
$\mathrm{SY}^{\mathrm{b}}$ & $10(0.36)$ & $5(0.13)$ & $15(0.24)$ \\
$\mathrm{ASY}^{\mathrm{c}}$ & $17(0.55)$ & $8(0.26)$ & $25(0.37)$ \\
Unknown & $18(0.59)$ & $15(0.26)$ & $33(0.36)$ \\
Total & $51(1.70)$ & $29(0.91)$ & $80(1.30)$ \\
\hline
\end{tabular}

\footnotetext{
${ }^{\mathrm{a}} \mathrm{HY}=$ hatch-year.

${ }^{\mathrm{b}} \mathrm{SY}=$ second-year.

${ }^{c}$ ASY $=$ after-second-year.
} 


\section{Red-tailed Hawk Strikes with Aircraft}

Compared with Phase I, there were $47 \%$ fewer red-tailed hawk strikes with aircraft and $67 \%$ fewer damaging redtailed hawk strikes during Phase II (Table 2). The average number of red-tailed hawks strikes per year during Phase I $(14.7 \pm 2.2)$ was not statistically different $\left(t_{4}=2.18\right.$, $P=0.08)$ from the average of $9.0 \pm 1.2$ hawk strikes per year that occurred during Phase II. However, we believe this represents an important difference in hawk strike rates resulting from the implementation of the 2 raptor hazard management programs.

Of the 80 red-tailed hawk strikes that were reported to have occurred at ORD during 2010-2016, 47 (59\%) contained age class information (Table 2). Overall, 14.9\%, $31.9 \%$ and $53.2 \%$ of the red-tailed hawk strikes with age class information involved HY, SY, and ASY hawks, respectively. Red-tailed hawk strikes involving HY, SY, and ASY birds were $83.3 \%, 50.0 \%$, and 52.9\% less, respectively, during the Phase II management program compared with the Phase I management program (Table 2).

\section{Economics of the Management Programs}

Based on cost information provided by Pullins et al. (2018), we estimated that the average cost to translocate each bird during Phase I was US\$79.95. Extrapolating to the total number of hawks translocated during Phase I, the total cost of mitigation translocations conducted was US\$63,001. Estimates do not include the costs of live-capturing and caring for the hawks while they are being held prior to translocation.

The estimated cost of one translocation event to Castle Rock State Park (the release site during Phase II) was US\$284. However, given more than one red-tailed hawk could be translocated during an individual event (assuming they were available for transport) the actual total cost per bird was consequently less. On average, we estimate the cost per bird for translocation to the Castle Rock State Park (the release site) was US\$68. Extrapolating to the total number of HY translocated during Phase II, the total cost for mitigation translocations during Phase II was US\$28,220, which is $55 \%$ less than the total cost for mitigation translocations conducted during Phase I.

During Phase I, there were 6 reported red-tailed hawk strikes that caused damage to aircraft, resulting in an estimated US\$513,384 in aircraft damage. During Phase II, there were only 2 damaging red-tailed hawk strikes reported, resulting in an estimated US $\$ 171,128$ in damages ( $67 \%$ less than during Phase I).

\section{DISCUSSION}

To our knowledge, our study is the first published work to evaluate the efficacy and economics of raptor hazard management programs at airports. Although the components of an individual raptor hazard management program might vary, the ultimate goal of any such mitigation program is to reduce the frequency of raptor-aircraft collisions and their potential effects on human-aviation safety.
Our findings demonstrate that a raptor hazard management program based on a combination of non-lethal hazing, mitigation translocation, and lethal removal (Phase II) was less expensive and more effective at reducing red-tailed hawk strikes than a management program focused primarily on mitigation translocations (Phase I). Fewer red-tailed hawk strikes might have been due to a reduced abundance of red-tailed hawks on the airfield, more management actions, directly removing more problematic red-tailed hawks, or some combination of these factors.

Detailed, airport-specific wildlife strike information is essential to allow for the evaluation of wildlife-hazard mitigation programs and actions at an individual airport or military airbase (Merriman et al. 2007, Pitlik and Washburn 2012). Although summaries and analyses of large amounts of wildlife strike information are very useful for documenting and understanding trends at a nation-wide scale (e.g., DeVault et al. 2011, Dolbeer 2018), airportspecific data collected within specified timeframes is necessary to evaluate the efficacy of mitigation programs. More importantly, as in our study, the wildlife strike data must include information such as age class. The raptor hazard management programs we evaluated involved various actions that were dependent on the age of the birds; consequently, hawk strike information must have the same level of detail to allow for effective comparisons. Age class information is rarely included in wildlife strike reports (Dolbeer 2018); we only had these details available because it is an important part of the raptor hazard management programs specific to ORD.

Pullins et al. (2018) found that the age of red-tailed hawks had a strong influence on the efficacy of mitigation translocations for this species. Younger (i.e., HY) hawks comprised a relatively low portion of the red-tailed hawk strikes at ORD during this study. This suggests that overall, HY are less frequently involved in aircraft strikes compared with older age classes, the 2 raptor hazard management programs were effective in reducing HY hawk strikes to a relative low level, or a combination of these factors occurred. Additional evaluations of the influence of age class on red-tailed hawk strike rates, as well as with other raptors, are needed to provide a better understanding of how age might influence the components of an effective raptor management program at airports.

Managing raptors and the associated strike risk at an airport is a financially costly component of many airport wildlife hazard management programs. We found that compared with the Phase I raptor hazard management program, the Phase II program cost approximately half as much and resulted in reduced economic costs due to hawk strikes by two-thirds. Further, if the airport wildlife biologist was traveling away from the airport to translocate a raptor(s), he or she was not on the airfield addressing other wildlife-related safety issues and thus the risk of wildlifeaircraft collisions could be increased. We recommend airports and military airfields incorporate translocation plans and conduct their own economic evaluations of their raptor hazard management programs to examine the financial and biological efficacy of those management actions. 
The conservation or population status of an individual species strongly influences management decisions related to the management of human-raptor conflicts, especially at airports (Washburn 2018). For highly abundant species, such as red-tailed hawks, a combination of lethal and nonlethal management tools is likely the most appropriate approach to mitigate threats to human-aviation safety. In contrast, lethal removal might not be a viable option when managing species with federal or state threatened or endangered status (e.g., short-eared owls [Asio flammeus], peregrine falcons [Falco peregrinus]) or those with special protection (e.g., bald eagles [Haliaeetus leucocephalus] and the Bald and Golden Eagle Protection Act [16 USC $\S \S 668-668 d]$; Washburn et al. 2015, Washburn 2018). In such situations, a non-lethal program (e.g., hazing, mitigation translocations) is likely the only option available to wildlife biologists and airport managers working to mitigate risks of raptor-aircraft collisions involving these species.

Management decisions on specific methods and practices to reduce the presence of hazardous wildlife, such as redtailed hawks, on airports involves a complex set of variables. A variety of ecological and socio-political factors, such as the biology of the species involved (Pullins et al. 2018), legal status of the species involved, direct economic costs of management actions, personal and corporate liability of wildlife strikes (Dale 2009), hidden logistical costs (Massei et al. 2010), and public perception of the management program in an increasingly social media-focused world (Graham et al. 2005, Cushing and Washburn 2014, Washburn 2018) might influence the selection of specific management actions to be taken. Although some variables are relatively straightforward, others are more complex when attempting to incorporate them into a decision matrix. Our study represents an important step in providing a scientific foundation for the development of efficacious management efforts to reduce the risk of raptor-aircraft collisions.

\section{MANAGEMENT IMPLICATIONS}

A variety of biological, financial, and socio-political factors might influence the composition of an integrated wildlife damage management program to decrease the risk posed by raptors to safe aircraft operations. We found that a raptor hazard management program based on a combination of non-lethal hazing, mitigation translocation, and lethal removal was less expensive and more effective at reducing redtailed hawk strikes than a management program focused primarily on mitigation translocations. We demonstrate that airport wildlife management decisions based on scientific data and biological information can aid in reducing wildlife strikes, financial losses, and ultimately airport liability while increasing human safety. Airport and wildlife managers can use information regarding the efficacy of raptor management programs to develop science-based management plans to effectively reduce the frequency and severity of red-tailed hawk collisions with aircraft.

\section{ACKNOWLEDGMENTS}

The Federal Aviation Administration and the Chicago Department of Aviation (the City of Chicago) provided funding and logistical support for this project. This research was supported [in part] by the intramural research program of the U.S. Department of Agriculture, Animal Plant Health Inspection Service, Wildlife Services. The Illinois Department of Natural Resources graciously provided access to the release site with (perceived) high-quality red-tailed hawk habitats. C. Bottom, A. Hoffman, S. Nau, S. Scully, A. Spencer, and J. Wisdom provided assistance in the field. We thank A. Hoffman, C. Boal (Associate Editor), A. Knipps (Editorial Assistant), and an anonymous reviewer for helpful comments on this manuscript. Opinions expressed in this study do not necessarily reflect current Federal Aviation Administration or U. S. Department of Agriculture policy decisions governing the control of wildlife on or near airports.

\section{LITERATURE CITED}

Airports Council International. 2017. Passenger Traffic 2017 Final. Airports Council International, Montréal, Québec, Canada. http://www.aci. aero/Data'Centre/Annual-Traffic-Data/Passengers/2017-final. Accessed 24 July 2019.

Allan, J., A. Baxter, and R. Callaby. 2016. The impact of variation in reporting practices on the validity of recommended birdstrike risk assessment procedures for aerodromes. Journal of Air Transport Management 57:101-106.

Anderson, A., D. S. Carpenter, M. J. Begier, B. F. Blackwell, T. L. DeVault, and S. A. Shwiff. 2015. Modeling the cost of bird strikes to US civil aircraft. Transportation Research Part D 38:49-58.

Baxter, A. T., and J. R. Allan. 2008. Use of lethal control to reduce habituation to blank rounds by scavenging birds. Journal of Wildlife Management 72:1653-1657.

Bibby, C. J., N. D. Burgess, D. A. Hill, and S. H. Mustoe. 2000. Bird census techniques. Second edition. Academic Press, London, United Kingdom.

Biteman, D. S., D. T. Collins, and B. E. Washburn. 2019. Sunshine, beaches, and birds: Managing raptor-aircraft collisions at airports in Southern California. Vertebrate Pest Conference 28:159-163.

Blackwell, B. F., and S. E. Wright. 2006. Collisions of red-tailed hawks (Buteo jamaicensis), turkey vultures (Cathartes aura), and black vultures (Coragyps atratus) with aircraft: implications for bird strike reduction. Journal of Raptor Research 40:76-80.

Bloom, P. H., W. S. Clark, and J. W. Kidd. 2007. Capture techniques. Pages 221-236 in D. M. Bird, and K. L. Bildstein, editors. Raptor research and management techniques. Hancock House Publishers, Blaine, Washington, USA.

Bub, H. 1991. Bird trapping and bird banding: a handbook for trapping methods all over the world. Cornell University Press, Ithaca, New York, USA.

Calsyn, D. E., L. P. Reinhardt, K. A. Ryan, and J. L. Wollenweber. 2012. Soil Survey of Cook County, Illinois. U.S. Department of Agriculture, Natural Resources Conservation Service, Washington, D.C., USA.

Chicago Department of Aviation. 2014. Chicago O'Hare International Airport Wildlife Hazard Management Plan. City of Chicago, Department of Aviation, Chicago O'Hare International Airport, Chicago, Illinois, USA.

Cleary, E. C., and R. A. Dolbeer. 2005. Wildlife hazard management at airports, a manual for airport personnel. Second edition. U.S. Department of Transportation, Federal Aviation Administration, Office of Airport Safety and Standards, Washington, D.C., USA.

Cushing, R., and B. E. Washburn. 2014. Exploring the role of Ospreys in education. Journal of Raptor Research (Special Issue) 48:414-421.

Dale, L. A. 2009. Personal and corporate liability in the aftermath of bird strikes: a costly consideration. Human-Wildlife Conflicts 3:216-225. 
DeVault, T. L., J. L. Belant, B. F. Blackwell, and T. W. Seamans. 2011. Interspecific variation in wildlife hazards to aircraft: implications for airport wildlife management. Wildlife Society Bulletin 35:394-402.

DeVault, T. L., B. F. Blackwell, and J. L. Belant, editors. 2013. Wildlife in airport environments: preventing animal-aircraft collisions through science-based management. Johns Hopkins Press, Bethesda, Maryland, USA.

DeVault, T. L., B. F. Blackwell, T. W. Seamans, M. J. Begier, J. D. Kougher, J. E. Washburn, P. R. Miller, and R. A. Dolbeer. 2018. Estimating interspecific economic risk of bird strikes with aircraft. Wildlife Society Bulletin 42:94-101.

Dolbeer, R. A. 2018. Wildlife strikes to civil aircraft in the United States 1990-2016. Federal Aviation Administration, National Wildlife Strike Database, Serial Report Number 23. Washington, D.C., USA.

Dolbeer, R. A., J. R. Belant, and J. L. Sillings. 1993. Shooting gulls reduces strikes with aircraft at John F. Kennedy International Airport. Wildlife Society Bulletin 21:442-450.

Federal Aviation Administration. 2018. Air Traffic Activity System: Airport Operations. Available online at https://aspm.faa.gov/opsnet/sys/ Airport.asp. Accessed 15 July 2019.

Graham, K., A. P. Beckerman, and S. Thirgood. 2005. Humanpredator-prey conflicts: ecological correlates, prey losses, and patterns of management. Biological Conservation 122:159-171.

Guerrant, T. L., C. K. Pullins, S. F. Beckerman, and B. E. Washburn. 2013. Managing raptors to reduce wildlife strikes at Chicago's O'Hare International Airport. Proceedings of the Wildlife Damage Management Conference 15:63-68.

Linnell, K. E., and B. E. Washburn. 2018. Assessing owl collisions with civil and U.S. Air Force aircraft. Journal of Raptor Research 52:282-290.

Merriman, J. W., C. W. Boal, T. L. Bayshore, P. J. Zwank, and D. B. Webster. 2007. Abundance of diurnal raptors in relation to prairie dog colonies: Implications for bird-aircraft strike hazard. Journal of Wildlife Management 71:811-815.

Marsh, R. E., W. A. Erickson, and T. P. Salmon. 1991. Bird hazing and frightening methods and techniques. California Department of Water Resources, Contract Number B 57211:233.

Massei, G., R. J. Quy, J. Gurney, and D. P. Cowan. 2010. Can translocations be used to mitigate human-wildlife conflicts? Wildlife Research 37:428-439.

McMillen, D. P. 2004. Airport expansions and property values: the case of Chicago's O'Hare Airport. Journal of Urban Economics 55:627-640.

Pfeiffer, M. B., B. F. Blackwell, and T. L. DeVault. 2018. Quantification of avian hazards to military aircraft and implications for wildlife management. PLoS ONE 13:e0206599.
Pitlik, T. J., and B. E. Washburn. 2012. Using bird strike information to direct effective management actions within airport environments. Proceedings of the Vertebrate Pest Conference 25:225-229.

Preston, C. R., and R. D. Beane. 2009. Red-tailed hawk (Buteo jamaicensis). Account 52 in A. Poole, and F. Gill, editors. The birds of North America, The Academy of Natural Sciences, Philadelphia, Pennsylvania, and The American Ornithologists' Union, Washington, D.C., USA.

Pullins, C. K., T. L. Guerrant, S. C. Beckerman, and B. E. Washburn. 2018. Mitigation translocation of red-tailed hawks to reduce raptoraircraft collisions. Journal of Wildlife Management 82:123-129.

Pyle, P. 2008. Identification guide to North American Birds. Part 2. Slate Creek Press, Point Reyes Station, California, USA.

Sauer, J. R., D. K. Nevin, J. E. Hines, D. J. Ziolkowski, Jr., K. L. Pardieck, J. E. Fallon, and W. A. Link. 2017. The North American Breeding Bird Survey, Results and Analysis 1966-20153. Version 02.07.2017. USGS Patuxent Wildlife Research Center, Laurel, Maryland, USA.

Schafer, L. M., and B. E. Washburn. 2016. Managing raptor-aircraft collisions on a grand scale: summary of a Wildlife Services raptor relocation program. Proceedings of Vertebrate Pest Conference 27:248-252.

Varland, D. E., J. A. Smallwood, L. S. Young, and M. N. Kochert. 2007. Marking techniques. Pages 221-236 in D. M. Bird and K. L. Bildstein, editors. Raptor research and management techniques. Hancock House, Blaine, Washington, USA.

Washburn, B. E. 2018. Human-raptor conflicts in urban settings. Pages 214-228 in C. W. Boal and C. R. Dykstra, editors. Urban raptors: ecology and conservation of birds of prey in cities. Island Press, Washington, D.C., USA.

Washburn, B. E., M. J. Begier, and S. E. Wright. 2015. Eagle-aircraft collisions: a growing problem in the airport environment. Journal of Raptor Research 49:192-200.

Washburn, B. E., G. E. Bernhardt, and L. A. Kutschbach-Brohl. 2011. Using dietary analyses to reduce the risk of wildlife-aircraft collisions. Human-Wildlife Interactions 5:204-209.

Witmer, G. W. 2011. Rodent population management at Kansas City International Airport. Human-Wildlife Interactions 5:240-246.

Zakrajsek, E. J., and J. A. Bissonette. 2005. Ranking the risk of wildlife species hazardous to military aircraft. Wildlife Society Bulletin 33:258-264.

Zar, J. H. 1996. Biostatistical analysis. Prentice-Hall, Upper Saddle River, New Jersey, USA.

Associate Editor: Boal. 